\title{
Yield Response of Sweet potato (Ipomoea batatas L. Lam) to Soil Solarization and Nutrient Management under Micro-fertigation Technique
}

\author{
Salvador R.M. and D.M. Bañoc* \\ Department of Agronomy, Visayas State University, Visca, Baybay City, Leyte, Philippines
}

\begin{abstract}
Sweet potato production is affected with different problems related to incidence of insect pests and diseases, and erratic climatic conditions which hamper the production by 41.33 to 42.22 percent, respectively. Thus, this study which was conducted aimed to determine the effects of soil solarization and micro-fertigation technique on the yield performance of sweet potato; determine the effect of nutrient management under micro-fertigation technique and evaluate the profitability of sweet potato production as influenced by soil solarization and micro-fertigation technique. This was laid out in split plot arranged in a Randomized Complete Block Design (RCBD) adopting three replications with two mainplots and four subplots. The main plot was designated as $\mathrm{M}_{1}-$ with solarization and $\mathrm{M}_{2}$ - without solarization while subplot treatments were designated as follows: $\mathrm{S}_{0}$ - no fertilizer application (control); $\mathrm{S}_{1}$ - conventional application of inorganic fertilizer; $S_{2}$ - application of inorganic fertilizer through micro-fertigation and $S_{3}$ - application of Aloe vera bio-organic liquid fertilizer through micro-fertigation. Soil solarization controlled weed population and produced higher total root yield of sweet poptato. Adoption of micro-fertigation technique increased root yield and produced larger and less-damaged roots. Morever, the application of aloe vera as bio-organic fertilizer enhanced higher root productivity and contributed lesser reduction of root yield caused by pests and diseases. Thereby, soil solarization with aloe vera application under micro-fertigation technique was the best option for sweet potato production to enhance root productivity, income and protection of plants from pest and disease damage especially in areas with unstable climatic conditions.
\end{abstract}

Keywords: Climate, Micro-fertigation, Nutrient management, Soil solarization, Sweet potato.

\section{Introduction}

Sweet potato (Ipomoea batatas L. Lam) is an annual herbaceous crop that has white and purple flowers, large nutritious storage roots and heart-shaped lobed leaves. This crop is one of the most important staple food in the tropical, subtropical and warm temperate regions. In Asia, people process sweet potato for snacks, delicacies and/or animal feed. It is rich in

\footnotetext{
*Corresponding author: DIONESIO M. BAÑOC

Email: dionesio.banoc@vsu.edu.ph

Received: June 12, 2020;

Accepted: July 10, 2020;

Published: July 11, 2020.
}

dietary fiber, calcium, complex carbohydrates and anti-oxidants. The young tops are rich in vitamin $\mathrm{B}, B$ carotene, iron, calcium, zinc and protein (Aquino, 2014).

In the Philippines, agriculture is a key sector which constitutes one-third of its total employment and one-tenth of the GDP thus, its key policy objective is focusing on food security and poverty alleviation through guaranteeing a stable supply of food at affordable prices (OECD, 2017). It is a challenge to develop technology to attain the said objectives. Production must increase and 
technology of other crops must be developed potentially. Production of rootcrops has a potential in the country as these crops can withstand varying climatic conditions.

Growing sweet potato in the Philippines is a major focus in agriculture. The main goal of the farmers is achieving higher yield and/or productivity per unit area. However, farmers nowadays are facing a lot of constraints in reaching this goal such as insect pests and diseases damage, lack of inputs, and more. It is a great challenge to the young agriculturist to address these issues and supply the food requirement of every Filipino. In dealing these issues, farmers must explore and find ways for the betterment of agriculture and these measures that must not damage the country's natural resources, but enhance productivity in a sustainable way. Introducing new technology is one of the best options in reaching towards the aforesaid goal. Modern agricultural technology can greatly affect the yield of a certain commodity through increasing the yield per unit area but reducing the production cost. However, the main concern is the preservation of the natural resources for the future generation.

The leading production problems are the incidence of insect pests and diseases, and erratic climatic conditions that hamper the production of sweet potato by 41.33 to 42.22 percent, respectively. One of the best approaches to reduce incidence of soilborne diseases which affect the development of fleshy roots is soil solarization and micro-fertigation. Soil solarization is a non-pesticidal technique which kills a wide range of soil pathogens, nematodes, and weed seeds by raising the soil temperature by placing black plastic sheets on moist soil during periods of high ambient temperature (D'addabbo et al., 2010), while micro-fertigation is a method of water management that can increase the efficiency and the effectiveness of water and nutrient inputs on sweet potato.

Another technology that can enhance the soil structure, chemical properties, water and nutrient holding capacity and Cation Exchange Capacity (CEC) is improved nutrient management. Nutrient management in the soil is necessary to balance the soil-plant relationship in order to meet the plant's need for nutrient without damaging the soil rather enhancing its properties. One of the good soil enhancer is an aloe vera-based organic liquid fertilizer with seaweed, natural ingredients and functional microorganisms. This supplies the nutrient requirement of the plants as well as enhances the microbial activity and chemical balance of the soil.

In this study, nutrients were supplied through micro-irrigation. In micro-fertigation, there was frequent application of small quantities of water and nutrient solutions on or below the soil surface as drops, tiny streams or miniature spray through emitters. Through this system of fertilizer application, plants received the needed nutrient gradually which indicated that there was continuous supply of all nutrients throughout their growth. FAO (2000) reported that increase in food production in the future was realized from the intensification of irrigated agriculture like micro-irrigation. Thus, this study was conducted to evaluate the effects of soil solarization and micro-fertigation technique on the yield performance of sweet potato; determine the effect of nutrient management under micro-fertigation technique and evaluate the profitability of sweet potato production as influenced by soil solarization and micro-fertigation technique.

\section{Materials and Methods}

This study was conducted in Brgy. Pangasugan, Baybay City, Leyte, Philippines from August 08, 2018 to February 09, 2019 under an upland ecosystem. An experimental area of $751.80 \mathrm{~m}^{2}$ was plowed and harrowed alternately two times 
at weekly interval using tractor. Soil beds were prepared for the solarized treatment plots after final land preparation.

Before planting, composite soil samples were collected randomly from the experimental area and were submitted for the determination of soil $\mathrm{pH}$ (Potentiometric Method at 1:1 soil-water ratio, PCARR, 1980), total N (Kjedahl Method, ISRIC, 1995), organic matter (Walkley-Black Method, Nelson and Sommers, 1982), available $\mathrm{P}$ (Olsen Method, Olsen et al., 1954), and exchangeable $\mathrm{K}$ (ammonium acetate) extraction method using atomic absorption spectrophotometry (ISRIC, 1995). For final soil analysis, another soil samples for each treatment plot were collected, processed and analyzed for the same soil parameters gathered.

The experimental area was laid out in split plot arranged in a Randomized Complete Block Design (RCBD) with soil solarization as the main plot and nutrient management under micro-fertigation technique as subplot which was replicated three times. The mainplot treatments were as follows: $\mathrm{M}_{1}$ - with soil solarization for eight weeks and $\mathrm{M}_{2}$ - without solarization. The subplot treatments adopted were as follows: $S_{0}-$ no fertilizer application (control), $\mathrm{S}_{1}-45-45-45 \mathrm{~kg} \mathrm{ha}^{-1} \mathrm{~N}, \mathrm{P}_{2} \mathrm{O}_{5}, \mathrm{~K}_{2} \mathrm{O}$ (Conventional method; no micro-fertigation), $\mathrm{S}_{2}$ - Micro-fertigation following the recommended rate (45-45-45 $\mathrm{kg} \mathrm{ha}^{-1} \mathrm{~N}, \mathrm{P}_{2} \mathrm{O}_{5}$, $\mathrm{K}_{2} \mathrm{O}$ ), $\mathrm{S}_{3}$ - Aloe vera liquid bio-organic fertilizer through micro-fertigation (10 L/ha.). Each plot occupied an area of $21.6 \mathrm{~m}^{2}(4.5 \mathrm{~m} \mathrm{x}$ $4.8 \mathrm{~m}$ ) with alleyways of one meter between subplots and two meters between replications.

After final land preparation, main plots were constructed in beds for easy installation of solarization plastics. This was done to insure that water could not accumulate during rainy periods. Solarization treatment was done by laying the plastic sheets with a thickness of $0.055 \mathrm{~mm}$ to the main plot that was solarized for two months. The edges of the plastic sheets were anchored into the soil by burying the edges in shallow trenches around the treated area. The solarization plastic remained in the solarized plots for eight weeks to ensure that solarization process in the soil reached the optimum radiation level needed. However, weeding was done to the unsolarized plots before planting. The soil was irrigated before the solarization plastic materials were installed. This was done through sprinkling of water to the surface of the soil using water sprinkler. The soil under the plastic sheets was saturated to at least 70 percent of field capacity in the upper layers and moist to a depth of 24 inches $(60 \mathrm{~cm})$ for soil solarization to be effective, this was 1.1 $\mathrm{m}^{3}$ to each plot (Elmore et al., 1997).

The micro-fertigation facility was put up with the model of Netafim's Family Drip System (FDS). This was the simple and applicable structure of micro-fertigation system suitable for the area. An area adjacent to the experimental field was allocated for the installation of tanks and irrigation head. After putting up the irrigation head, main irrigation lines installed were connected to the primary irrigation pipe lines. Then, the secondary lines with $30 \mathrm{~cm}$ dripper points were connected to the primary lines. These secondary lines were installed on the plots with micro-fertigation treatment. This was the set up before planting. However, computation of water requirement on each fertigation schedule with respect to its growth stages is given in the subsequent pages. Fertigation during rainfall still continued but at a reduced rate.

This was done based on the amount of precipitation. Then the amount of rainfall was computed by putting an evaporating pan in the area. After the amount of rainfall was obtained, it was deducted from the rate of fertigation. The evaporating pan provided the data on the amount of rainfall at the specific period. 
A. Irrigation schedule for early growth stage:

1. Total water discharge $(\mathrm{Q})$ :

$\mathrm{Q}=$ total number of drippers $x$ dripper discharge per hour

$=96 \times 1.6 \mathrm{~L} / \mathrm{hr}$.

$=153.6 \mathrm{~L} / \mathrm{hr}$. per plot

2. Water requirement per plot/week

Water needed $=$ plot area $x$ water requirement in each growth stages (DAFF, 2011)

$$
\begin{aligned}
=21.6 \mathrm{~m}^{2} \times 0.18 \mathrm{~m} & \\
= & 0.3888 \mathrm{~m}^{2} \text { or } 388.8 \mathrm{li}
\end{aligned}
$$

Fertigation schedule/week

Schedule $=$ water needed $/$ plot $\div$ total water discharge/ plot

$$
\begin{aligned}
& =388.8 \mathrm{li} \div 153.6 \mathrm{~L} / \mathrm{hr} . \\
& =2.53 \text { hours } / \text { week }
\end{aligned}
$$

3. Fertigation schedule per growth stage Early growth stage $=4 \mathrm{WAP} \times 2.53 \mathrm{hr}$. /week

$$
=10.12 \text { hours }
$$

Schedule $=30$ days $\div 10.12$ hours

$$
=2.96 \text { days or } 3 \text { days interval of }
$$

fertigation in early growth stage

B. Irrigation schedule for mid-growth stage:

1. Total water discharge (Q): $153.6 \mathrm{~L} / \mathrm{hr}$. per plot

2. Water requirement per plot/week: 0.864 $\mathrm{m}^{2}$ or $864 \mathrm{li}$

3. Fertigation schedule/week

Schedule $=$ water needed $/$ plot $\div$ total water discharge/plot

$=864 \mathrm{li} \div 153.6 \mathrm{~L} / \mathrm{hr}$.

$=5.63$ hours/week or 6 times a

week with one-hour irrigation time

$=2.815$ hours/week or 3 times a

week with two-hours irrigation time

4. Fertigation schedule per growth stage

Early growth stage $=8 \mathrm{WAP} x 2.815 \mathrm{hr}$. / week

$$
=22.5 \text { hours }
$$

Schedule $=56$ days $\div 22.5$ hours

$$
=2.50 \text { days or } 3 \text { days interval of }
$$

fertigation in mid-growth stage

\section{Irrigation schedule for maturity stage:}

1. Total water discharge (Q): $153.6 \mathrm{~L} / \mathrm{hr}$. per plot

2. Water requirement per plot/week: 0.432 $\mathrm{m}^{2}$ or $432 \mathrm{li}$

3. Fertigation schedule/week

Schedule $=$ water needed $/$ plot $\div$ total water discharge/plot

$=432 \mathrm{li} \div 153.6 \mathrm{~L} / \mathrm{hr}$.

$=2.81$ hours/ week or 3 times a

week with one-hour irrigation time
4. Fertigation schedule per growth stage Early growth stage $=4 \mathrm{WAP} x 2.81 \mathrm{hr}$. /week

$$
=11.25 \text { hours }
$$

Schedule $=30$ days $\div 11.25$ hours

$$
=2.66 \text { days or } 3 \text { days interval of }
$$

fertigation in maturity stage

\section{Preparation and Planting of Sweet potato Cuttings}

Sweet potato (NSIC Sp30) cuttings with mature apical vines at $30 \mathrm{~cm}$ long were used. These were buried in the soil at a depth of $10 \mathrm{~cm}$ in a vertical position with one cutting per hill at a distance of $0.75 \mathrm{~m}$ between rows and $0.30 \mathrm{~m}$ between hills. This was also the distance of the drippers in the fertigation lines where planting was done immediately after the installation of micro-fertigation set up.

\section{Care and Management}

Replanting of missing hills in all treatment plots was done one week after planting. Hilling up and hand weeding were done using bolo in controlling weeds as well as in loosening the soil. Solophos (0-20-0), urea (21-0-0) and Muriate of potash - MOP (0-0-60) were used as fertilizers to satisfy the desired rate of 45-45-45 $\mathrm{kg} \mathrm{ha}^{-1} \mathrm{~N}, \mathrm{P}_{2} \mathrm{O}_{5}, \mathrm{~K}_{2} \mathrm{O}$. Phosphorus was applied basally before planting while the rest of the nutrients ( $\mathrm{N}$ and $\mathrm{K}$ ) were applied through micro-fertigation. However, subplots had Aloe vera bio-organic fertilizer applied through micro-fertigation at the rate of $10 \mathrm{~L} / \mathrm{ha}$. and a dilution of $200 \mathrm{~L}$ water : 1 liter Aloe vera ratio was followed since this bio-organic fertilizer has sufficient nutrient composition (Table 3) as mentioned by Alovebali (2011) and cited by Salvador and Bañoc (2020).

In fertilizer application, $S_{1}$ was designated with the specific period of time (Table 1) while $S_{2}$ and $S_{3}$ adopted the fertigation schedule shown in Table 2, since the fertilizers of these treatments were diluted with water and distributed through irrigation lines. Harvesting was done when the majority of the plants 
reached maturity. All plants within the harvestable area were taken from the four inner rows in each plot excluding the two border rows and one end hill in each row. Vines were cut using bolo at the base of the plant. Extra care during harvesting was observed to minimize damage of the fleshy roots. The harvested fleshy roots were cleaned by removing the soil that adhered to them. No washing was done to avoid damage during storage. Then the harvested roots were classified into marketable and non-marketable ones.

\section{Weed Occurrence and Population}

Weed occurrence and population were undertaken through weed identification and their corresponding weed density. Weed identification was done by classifying and then identifying the five major weed species that were present in a quadrat during sampling period in each treatment plot. Identification of the species in a quadrat included proper naming relative to its scientific name, English name and local name. Determining weed density was done by getting the fresh weight of weeds present in the $50 \mathrm{~cm} \times 50 \mathrm{~cm}$ quadrat two months after planting.

\section{Pests and Diseases Incidence}

Pest damage and/or infestation was noted only after harvesting the experimental plants. This was obtained by counting the infested roots and assessing the degree of infestation from tolerable to worst following the rating scale adopted by Oso and Borisade, 2017 such as the following: $1=0-20 \%$ damage, $2=21-40 \%$ damage, $3=41-60 \%$ damage, $4=61-80 \%$ damage and $5=81-100 \%$ damage.

\section{Data Gathered}

The data gathered for the yield and yield component parameters were the number of marketable and non-marketable roots per hectare, marketable and non-marketable root yield $\left(\mathrm{t} \mathrm{ha}^{-1}\right)$ and total root yield $\left(\mathrm{t} \mathrm{ha}^{-1}\right)$. Data relative to harvest index, occurrence and weed population, pests and diseases incidence, cost and return analysis and meteorological data were also gathered. The meteorological data on total weekly rainfall $(\mathrm{mm})$, maximum and minimum daily temperatures $\left({ }^{\circ} \mathrm{C}\right)$ and relative humidity $(\% \quad \mathrm{RH})$ throughout the growing period of sweet potato were obtained from the records of the Philippine Atmospheric Geophysical and Astronomical Services Administration (PAGASA) Station, Visayas State University (VSU), Visca, Baybay City, Leyte, Philippines. After gathering all the data, the means were taken and analysis of variance (ANOVA) was performed using Statistical Tool for Agriculture Research (STAR) software. Comparison between treatment means was done using the Tukeys' Honest Significant Difference (HSD) Test.

Table 1. Actual amount of fertilizers applied per plot $\left(21.6 \mathrm{~m}^{2}\right)$

\begin{tabular}{ccccc}
\hline Treatment & Type of Fertilizer & \multicolumn{3}{c}{ Growth Duration } \\
\cline { 3 - 5 } & & Early Growth & Mid-Growth & Maturity \\
\hline $\mathbf{S}_{\mathbf{0}}$ & None & - & - & - \\
\hline $\mathbf{S}_{\mathbf{1}}$ & & $(30 \mathrm{DAP})$ & $(60 \mathrm{DAP})$ & - \\
& Solophos & $540.0 \mathrm{~g}$ & - & - \\
& Urea & $346.0 \mathrm{~g}$ & $346.0 \mathrm{~g}$ & - \\
& MOP & $81.0 \mathrm{~g}$ & $81.0 \mathrm{~g}$ & - \\
\hline $\mathbf{S}_{\mathbf{2}}$ & Solophos & $540.0 \mathrm{~g}$ & - & - \\
& Urea & $162.0 \mathrm{~g}$ & $352.4 \mathrm{~g}$ & $179.0 \mathrm{~g}$ \\
& MOP & $37.8 \mathrm{~g}$ & $82.2 \mathrm{~g}$ & $42.0 \mathrm{~g}$ \\
\hline $\mathbf{S}_{\mathbf{3}}$ & Aloe vera & $5.04 \mathrm{ml}$ & $10.96 \mathrm{ml}$ & $5.6 \mathrm{ml}$ \\
\hline
\end{tabular}


Table 2. Fertigation schedule of subplots two and three.

\begin{tabular}{|c|c|c|c|c|}
\hline \multirow[t]{2}{*}{ Growth stages } & \multicolumn{2}{|c|}{$\begin{array}{c}\text { Subplot } 2 \\
\text { (DAP) }\end{array}$} & \multicolumn{2}{|c|}{$\begin{array}{l}\text { Subplot } 3 \\
\text { (DAP) }\end{array}$} \\
\hline & $\mathrm{M}_{1}$ & $\mathrm{M}_{2}$ & $\mathrm{M}_{1}$ & $\mathrm{M}_{2}$ \\
\hline \multirow{10}{*}{ Early growth } & 3 & 3 & 3 & 3 \\
\hline & 6 & 6 & 6 & 6 \\
\hline & 9 & 9 & 9 & 9 \\
\hline & 12 & 12 & 12 & 12 \\
\hline & 15 & 15 & 15 & 15 \\
\hline & 18 & 18 & 18 & 18 \\
\hline & 21 & 21 & 21 & 21 \\
\hline & 24 & 24 & 24 & 24 \\
\hline & 27 & 27 & 27 & 27 \\
\hline & 30 & 30 & 30 & 30 \\
\hline \multirow{19}{*}{ Midgrowth } & 34 & 34 & 34 & 34 \\
\hline & 37 & 37 & 37 & 37 \\
\hline & 40 & 40 & 40 & 40 \\
\hline & 43 & 43 & 43 & 43 \\
\hline & 46 & 46 & 46 & 46 \\
\hline & 49 & 49 & 49 & 49 \\
\hline & 52 & 52 & 52 & 52 \\
\hline & 55 & 55 & 55 & 55 \\
\hline & 58 & 58 & 58 & 58 \\
\hline & 61 & 61 & 61 & 61 \\
\hline & 64 & 64 & 64 & 64 \\
\hline & 67 & 67 & 67 & 67 \\
\hline & 70 & 70 & 70 & 70 \\
\hline & 73 & 73 & 73 & 73 \\
\hline & 76 & 76 & 76 & 76 \\
\hline & 79 & 79 & 79 & 79 \\
\hline & 81 & 81 & 81 & 81 \\
\hline & 84 & 84 & 84 & 84 \\
\hline & 87 & 87 & 87 & 87 \\
\hline \multirow{4}{*}{ Maturity } & 90 & 90 & 90 & 90 \\
\hline & 93 & 93 & 93 & 93 \\
\hline & 96 & 96 & 96 & 96 \\
\hline & 99 & 99 & 99 & 99 \\
\hline
\end{tabular}

Table 3. Nutrient Composition of Aloe vera bio-organic fertilizer (Alovebali, 2011)

\begin{tabular}{lcc|lcr}
\hline Nutrients & Unit & Amount & \multicolumn{1}{|c}{ Functional Microorganisms } & Unit & Volume \\
\hline Nitrogen & $\%$ & 1.14 & Rhizobium (Bradyrhizobium japonicum) & $\mathrm{cfu} \mathrm{ml}^{-1}$ & $4.8 \times 10^{8}$ \\
Phosphorus & $\%$ & 1.02 & Azospirillum sp. & $\mathrm{cfu} \mathrm{ml}^{-1}$ & $1.2 \times 10^{8}$ \\
Potassium & $\%$ & 1.03 & Bacillus subtilis & $\mathrm{cfu} \mathrm{ml}^{-1}$ & $6.5 \times 10^{9}$ \\
Organic carbon & $\%$ & 5.08 & Aspergillus niger & $\mathrm{cfu} \mathrm{ml}^{-1}$ & $5.0 \times 10^{8}$ \\
Iron & $\mathrm{ppm}$ & 345.23 & Lactobacillus sp. & $\mathrm{cfu} \mathrm{ml}^{-1}$ & $2.7 \times 10^{9}$ \\
Boron & $\mathrm{ppm}$ & 371.58 & Phosphate Solubilizing Bacteria & (Pseudomonas putida) & \\
Cupper & $\mathrm{ppm}$ & 23.30 & & & \\
Manganese & $\mathrm{ppm}$ & 58.85 & & & \\
Molybdenum & $\mathrm{ppm}$ & $<0.20$ & & & \\
Zinc & $\mathrm{ppm}$ & 21.70 & & & \\
Cobalt & $\mathrm{ppm}$ & $<0.05$ & & & \\
\hline
\end{tabular}




\section{Results and Discussion}

The data on average weekly rainfall $(\mathrm{mm})$, average daily minimum and maximum temperatures $\left({ }^{\circ} \mathrm{C}\right)$ and relative humidity $(\%)$ during the conduct of the study are shown in Figure 1. The average weekly rainfall throughout the conduct of the study reached $135.54 \mathrm{~mm}$ which ranged from $0.25-14.25$ $\mathrm{mm}$ which was equivalent to a total rainfall of $948.78 \mathrm{~mm}$. This amount of rainfall was adequate and considered favourable for sweet potato crop. Valenzuela et al., (2019) reported that sweet potato develops well in a total rainfall range of 500 to $1,300 \mathrm{~mm}$ per growth cycle with optimum levels at 900 to $1,300 \mathrm{~mm}$. The minimum and maximum temperatures for the whole growing period ranged from 22.68$26.16^{\circ} \mathrm{C}$ and $27.21-33.10{ }^{\circ} \mathrm{C}$, respectively, and the average relative humidity was $84.17 \%$. Ramirez (1991) reported that sweet potato grows well in temperature which ranged from $25-30^{\circ} \mathrm{C}$ during the day and $15-20^{\circ} \mathrm{C}$ during the night. Thus, the average temperature and relative humidity were both favourable for the growth and development of the crop.

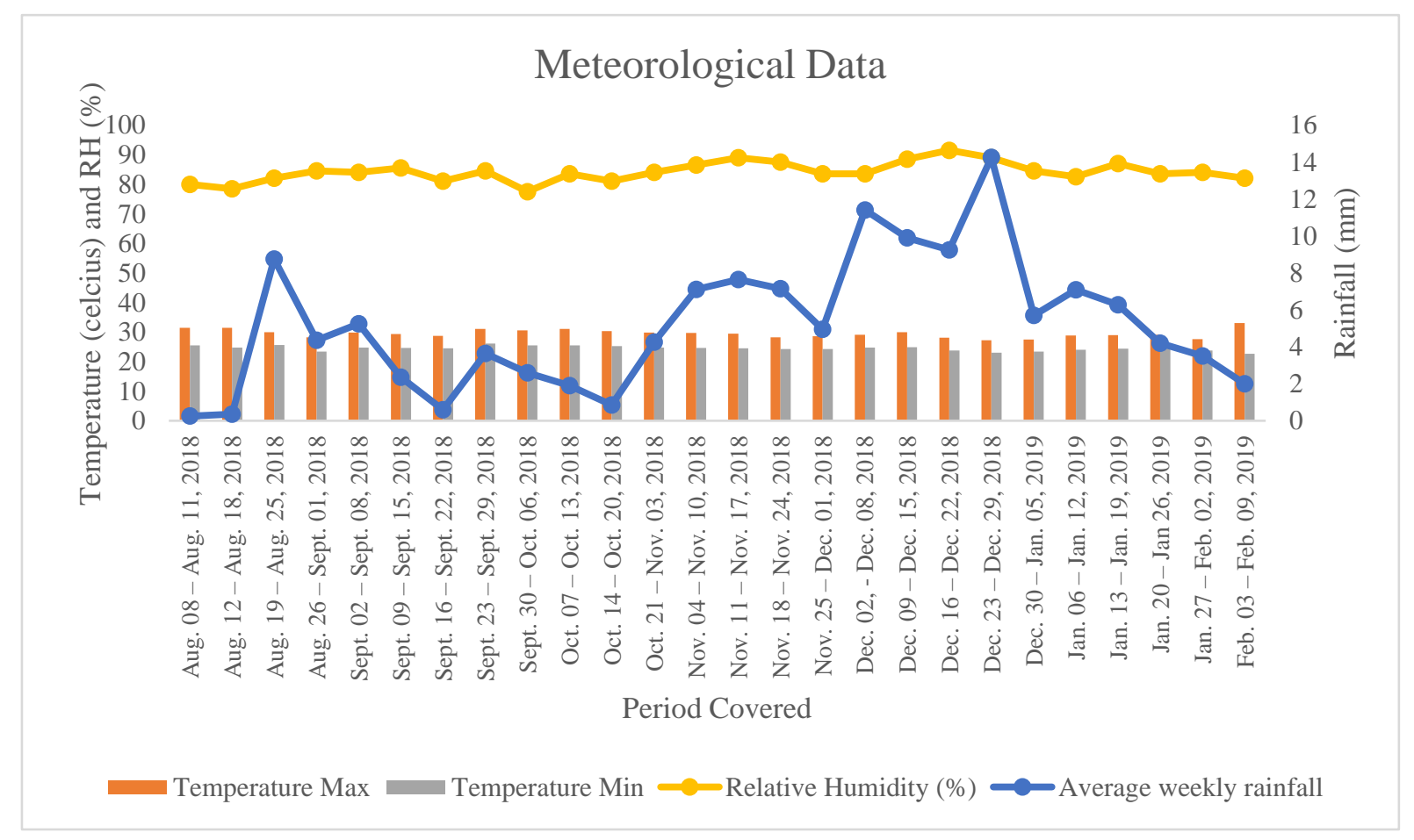

Figure 1. The agro-meteorological data during the conduct of the study

\section{Soil Chemical Properties}

The result of initial soil analysis showed that the experimental area had a $\mathrm{pH}$ of $7.21,3.53 \%$ organic matter, $0.18 \%$ total $\mathrm{N}, 4.23 \mathrm{mg} \mathrm{kg}^{-1}$ available $\mathrm{P}$ and $0.78 \mathrm{me} 100 \mathrm{~g}^{-1}$ of exchangeable $\mathrm{K}$ (Table 4). This result indicated that the experimental area had neutral $\mathrm{pH}$, low organic matter and total $\mathrm{N}$ content, very low available $\mathrm{P}$ but high in exchangeable K (Landon, 1991).
Final analysis showed an increase of soil $\mathrm{pH}$ on the solarized and fertigated treatments while a decrease was noted on the non-solarized and non-fertigated treatments. The increased $\mathrm{pH}$ on solarized and fertigated treatments was attributed to possible leaching and mainly due to the dilution of fertilizer materials during the entire duration of the experiment through irrigation. 
Table 4. Soil chemical properties before planting and after harvest of sweet potato (Ipomoea batatas L. Lam) as influenced by soil solarization and nutrient management under micro-fertigation technique

\begin{tabular}{|c|c|c|c|c|c|}
\hline Treatment & $\begin{array}{c}\mathrm{pH} \\
(1: 1)\end{array}$ & $\begin{array}{c}\text { Organic } \\
\text { matter }(\%)\end{array}$ & $\begin{array}{c}\text { Total N } \\
(\%)\end{array}$ & $\begin{array}{l}\text { Available P } \\
\left(\mathrm{mg} \mathrm{kg}^{1}\right)\end{array}$ & $\begin{array}{l}\text { Exchangeable } \\
\mathrm{K}\left(\mathrm{me} 100 \mathrm{~g}^{-1}\right)\end{array}$ \\
\hline Initial Analysis & 7.21 & 3.53 & 0.18 & 4.23 & 0.78 \\
\hline \multicolumn{6}{|l|}{ Final Analysis } \\
\hline \multicolumn{6}{|l|}{ Soil Solarization } \\
\hline $\mathrm{M}_{1}-$ with solarization & 7.42 & 5.83 & 0.47 & 12.08 & 0.24 \\
\hline $\begin{array}{l}\mathrm{M}_{2}-\text { without } \\
\text { solarization }\end{array}$ & 6.91 & 5.65 & 0.36 & 11.13 & 0.24 \\
\hline Mean & 7.17 & 5.74 & 0.41 & 11.60 & 0.24 \\
\hline \multicolumn{6}{|l|}{ Nutrient Management } \\
\hline $\mathrm{S}_{0}-$ control & 6.62 & 5.58 & 0.27 & 8.41 & 0.22 \\
\hline $\begin{array}{l}\mathrm{S}_{1}-\text { Conventional } \\
\text { method; no micro- } \\
\text { fertigation }\end{array}$ & 6.71 & 3.84 & 0.23 & 6.99 & 0.20 \\
\hline $\begin{array}{l}\mathrm{S}_{2}-\text { Micro-fertigation } \\
\text { following } \\
\text { recommended rate }\end{array}$ & 7.63 & 5.66 & 0.51 & 11.83 & 0.28 \\
\hline $\begin{array}{l}\mathrm{S}_{3}-\text { Aloe vera bio- } \\
\text { organic liquid } \\
\text { fertilizer through } \\
\text { micro-fertigation }\end{array}$ & 7.74 & 7.90 & 0.65 & 19.16 & 0.25 \\
\hline Mean & 7.18 & 5.75 & 0.41 & 11.60 & 0.24 \\
\hline
\end{tabular}

Relative to organic matter (OM), there was an increase on $\mathrm{OM}$ in all treatments adopted. Total $\mathrm{N}$ showed an increase in all treatments but decrease on control plot and non-fertigated conventional fertilizer application. Microfertigated treatments showed an increase on $\mathrm{N}$ which was supplied in dissolved form which was highly available to the plants; on the other hand, its application in granular form took time to make it available. The increasing $\mathrm{N}$ was attributed to the hydrolysis process of nitrogen fertilizer when diluted with water. Available $\mathrm{P}$ also increased in all treatments while exchangeable $\mathrm{K}$ decreased. O'Sullivan et al. (1997) reported that a $20 \mathrm{t} \mathrm{ha}^{-1}$ sweet potato crop removes approximately $100 \mathrm{~kg} \mathrm{~K} \mathrm{ha}^{-1}$ on the storage roots, and considerably more is removed if both roots and vines are harvested. Even soils which are naturally high in potassium may become depleted after several successive cropping.

Yield and Yield Components and Harvest Index 
Statistical analysis showed that the number of marketable and non-marketable roots and total root yield were significantly affected by soil solarization (Table 5). Results revealed that the number of marketable and non-marketable roots were significantly higher on the nonsolarized treatments with 79.08 roots and 39.08 roots, respectively, than those of solarized treatments.

Composition of aloe vera bio-organic liquid fertilizer showed that this material contains both macro $\left(\mathrm{N}, \mathrm{P}_{2} \mathrm{O}_{5}, \mathrm{~K}_{2} \mathrm{O}\right)$ and micro nutrients (Fe, Bo, Mn, Mo, Zn, Co) which are essential for plant growth and development. Nutrient contents are just small compared to the commercial granulated synthetic fertilizers but these contain functional microorganisms ranging from $1.2 \times 10^{8}-7.4 \times 10^{9} \mathrm{cfu} \mathrm{ml}^{-1}$ which are beneficial in preventing incidence of pests and diseases as well as nutrient absorption and availability. These microorganisms increase the immune system of the crop and widen its scope of nutrient absorption in roots (Alovebali, 2011). This basically means that solarization did produce lesser number of roots but bigger root size since both treatments did not significantly differ in root yield. Result might be attributed to the enhancing capacity of soil on solarization through rapid decomposition of weeds in the area covered with plastic. Improved soil tilth and the increased availability of nitrogen, calcium, and magnesium also accounted for increases in plant growth following soil solarization (Hagan and Gazaway, 2000).

Table 5. Yield and yield components and harvest index (HI) of sweet potato as influenced by soil solarization and nutrient management under micro-fertigation technique

\begin{tabular}{|c|c|c|c|c|c|c|}
\hline \multirow[b]{2}{*}{ Treatment } & \multicolumn{2}{|c|}{ Number of roots plot $^{-1}(\mathrm{~g})$} & \multicolumn{2}{|c|}{ Root Yield $\left(\mathrm{t} \mathrm{ha}^{-1}\right)$} & \multirow{2}{*}{$\begin{array}{l}\text { Total Root } \\
\text { Yield } \\
\left(\mathrm{t} \mathrm{ha}^{-1}\right) \\
\end{array}$} & \multirow[b]{2}{*}{ HI } \\
\hline & Marketable & $\begin{array}{c}\text { Non- } \\
\text { marketable }\end{array}$ & Marketable & $\begin{array}{c}\text { Non- } \\
\text { marketable }\end{array}$ & & \\
\hline Soil Solarization & & & & & & \\
\hline $\mathrm{M}_{1}-$ with solarization & $75.08 b$ & $33.92 b$ & 18.75 & 2.94 & $21.69 \mathrm{a}$ & 0.42 \\
\hline $\mathrm{M}_{2}$ - without solarization & $79.08 \mathrm{a}$ & $39.08 \mathrm{a}$ & 16.70 & 2.93 & $19.64 \mathrm{~b}$ & 0.42 \\
\hline Mean & 77.08 & 36.50 & 17.73 & 2.94 & 20.67 & 0.42 \\
\hline Nutrient Management & & & & & & \\
\hline $\mathrm{S}_{0}-$ Control & $82.50 \mathrm{a}$ & 34.67 & $9.31 \mathrm{~d}$ & $2.62 b$ & $11.93 \mathrm{~d}$ & $0.36 \mathrm{c}$ \\
\hline $\begin{array}{l}\mathrm{S}_{1}-\text { Conventional method; no } \\
\text { micro-fertigation }\end{array}$ & $79.67 \mathrm{a}$ & 39.00 & $13.06 \mathrm{c}$ & $3.06 \mathrm{a}$ & $16.12 \mathrm{c}$ & $0.43 b$ \\
\hline $\begin{array}{l}S_{2}-\text { Micro-fertigation following } \\
\text { recommended rate }\end{array}$ & $75.00 \mathrm{~b}$ & 36.67 & $19.44 b$ & $3.02 \mathrm{a}$ & $22.46 b$ & $0.46 \mathrm{a}$ \\
\hline $\begin{array}{l}\mathrm{S}_{3}-\text { Aloe bio-organic liquid } \\
\text { fertilizer through micro- } \\
\text { fertigation }\end{array}$ & $71.17 b$ & 35.67 & $29.09 \mathrm{a}$ & $3.03 \mathrm{a}$ & $32.12 \mathrm{a}$ & $0.46 \mathrm{a}$ \\
\hline Mean & 77.08 & 36.50 & 17.73 & 2.93 & 20.66 & 0.43 \\
\hline $\mathrm{CV}$ a $(\%)$ & 1.21 & 10.71 & 11.93 & 7.14 & 7.22 & 5.70 \\
\hline $\mathrm{CV} \mathrm{b}(\%)$ & 4.43 & 15.49 & 5.55 & 8.92 & 6.07 & 5.00 \\
\hline
\end{tabular}

Treatment means within the same column followed by a common letters are not significantly different from each other at 5\% level, Tukeys Test. 
For nutrient management, however, the number of marketable roots, yield of marketable and non-marketable roots, total root yield and harvest index were significantly affected. Treatments without micro-fertigation were significantly higher on the number of marketable roots than those treatments with micro-fertigation. This result was attributed to the higher availability and closer proximity in absorbing nutrient for the plants effective growth and development at early root bulking stage but did not sustain during the later stage. The nearer and the higher availability of nutrients for crop uptake; the bigger was the chance for faster growth, development and enlargement of the roots hence, producing bigger roots. In terms of marketable root yield and total root yield, application of aloe bioorganic liquid fertilizer through microfertigation was significantly higher than the other fertigated treatments. Result could be due to its humic acid content which magnified the macro and micro nutrients needed by plants, microorganisms which provided disease free soil, presence of micro nutrients available for the immune system of the plants and improvement in soil structure and soil chemical properties. Aloe vera bio-organic liquid fertilizer contains functional microorganisms that fix physical and chemical properties in the soil and root tissue, and solubilize phosphates. This finding conformed the study of Alovebali, (2011) which explained that humic acid increases the cation exchange capacity in the soil and improves the efficiency on the usage of inorganic fertilizers. Likewise, microfertigation out-yielded the conventional application and the untreated control. This was due to the direct and continuous distribution of nutrients in micro-fertigated crop. The efficiency of the absorbed nutrients and conversion of photosynthates to fleshy roots as shown in the harvest index values that microfertigated treatments were significantly higher than the non-micro-fertigated treatments.

Interaction effects between solarization and nutrient management on the number of nonmarketable roots of sweet potato is shown in Table 6. The result showed that during solarization, micro-fertigation following the recommended rate was significantly higher on the number of non-marketable roots. Similarly, non-solarized plots with conventional application of fertilizer also obtained significantly higher results on the number of non-marketable roots. This implies that even without solarization the crop could produce numerous number of roots but majority of said roots were undeveloped, and thereby smaller in sizes.

Table 6. Interaction effect between solarization and nutrient management on the number of nonmarketable roots plot $^{-1}$ of sweet potato as influenced by soil solarization and nutrient management under micro-fertigation technique

\begin{tabular}{ccccc}
\hline \multirow{2}{*}{ Solarization } & Control & $\begin{array}{c}\text { Conventional } \\
\text { method; no micro- } \\
\text { fertigation }\end{array}$ & $\begin{array}{c}\text { Micro-fertigation } \\
\text { following } \\
\text { recommended rate }\end{array}$ & $\begin{array}{c}\text { Aloe vera bio-organic liquid } \\
\text { fertilizer through micro- } \\
\text { fertigation }\end{array}$ \\
\hline with solarization & $30.00 \mathrm{c}$ & $32.33 \mathrm{bc}$ & $40.67 \mathrm{ab}$ & $32.67 \mathrm{bc}$ \\
without solarization & $39.33 \mathrm{abc}$ & $45.67 \mathrm{a}$ & $32.67 \mathrm{bc}$ & $38.67 \mathrm{abc}$ \\
\hline Mean & 34.67 & 39.00 & 36.67 & 35.67 \\
\hline
\end{tabular}

Means with the same letter are not significantly different from each other at 5\% level, Tukeys Test. 
Micro-fertigation of inorganic fertilizer

following the recommended rate increased the number of non-marketable roots of solarized sweet potato. In effect, this hampered root development due to slow absorption of nutrients for proper root growth and development of the crop, because during early growth stage most microorganisms in the soil supposedly useful in nutrient translocation were eliminated on solarization (D'addabbo et al., 2010). Olajire-Ajayi et al. (2015) stipulated that these microorganisms in the soil create foods for the plants like nitrogen, carbon, oxygen, hydrogen, phosphorus, potassium and trace minerals. In addition, Parr et al. (1994) as cited by Olajire-Ajayi et al. (2015) stressed that microorganisms convert the NPK and minerals in the soil into a form that plants can utilize for their proper growth and development.
Interaction effects between soil solarization and nutrient management on the marketable root yield of sweet potato is presented in Table 7 . Soil solarization increased the marketable root yield in micro-fertigated plants with aloe vera bio-organic liquid fertilizer gaining the highest marketable yield (30.99 $\left.\mathrm{t} \mathrm{ha}^{-1}\right)$. Marketable root yield of sweet potato declined with microfertigation using recommended rate $(20.52 \mathrm{t}$ ha $\left.{ }^{1}\right)$ and aloe vera bio-organic liquid fertilizer in non-solarized plots $\left(27.19 \mathrm{tha}^{-1}\right)$. This was due to the process of solarization which almost eliminated all the microorganisms in the soil. However, the solarized treatment with aloe vera bio-organic liquid fertilizer supplied abundant beneficial microorganisms that enhanced soil condition which favored the growth and development of roots

Table 7. Interaction effect between solarization and nutrient management on marketable root yield ( $\mathrm{t}$ $\mathrm{ha}^{-1}$ ) of sweet potato as influenced by soil solarization and nutrient management under microfertigation technique

\begin{tabular}{ccccc}
\hline & \multicolumn{4}{c}{ Yield of Marketable Roots $\left(\mathrm{t} \mathrm{ha}^{-1}\right)$} \\
\cline { 2 - 5 } Solarization & Control & $\begin{array}{c}\text { Conventional } \\
\text { method; no micro- } \\
\text { fertigation }\end{array}$ & $\begin{array}{c}\text { Micro-fertigation } \\
\text { following } \\
\text { recommended rate }\end{array}$ & $\begin{array}{c}\text { Aloe vera bio- } \\
\text { organic liquid } \\
\text { fertilizer through } \\
\text { micro-fertigation }\end{array}$ \\
\hline With solarization & $10.40 \mathrm{de}$ & $13.09 \mathrm{~d}$ & $20.52 \mathrm{c}$ & $30.99 \mathrm{a}$ \\
Without solarization & $8.22 \mathrm{e}$ & $13.04 \mathrm{~d}$ & $18.36 \mathrm{c}$ & $27.19 \mathrm{~b}$ \\
\hline Mean & 9.31 & 13.07 & 19.44 & 29.09 \\
\hline
\end{tabular}

Means with the same letter are not significantly different from each other at 5\% level, Tukeys Test. 


\section{Weed Population, Pests and Disease Incidence}

Analysis of variance revealed that solarized plots had significantly lower weed density than that of non-solarized plots (Table 8). This was attributed to the increase in temperature under solarization treatment which killed almost all of the weed seeds present in the soil (Salvador, 2019). The result conformed the findings of Horowitz and Herzlinger (1983) on no emergence of weeds in solarized plots during solarization period. However, weed incidence only occurred after removal of the plastic cover. Many annual weeds, both summer species such as pigweed (Amaranthus spp.) and common purslane (Portulaca oleracea L.) were well controlled by solarization. Euphorbia hirta L., Ageratum conyzoides L. and Rottboellia cochinchinensis were also observed in the nonsolarized plots 45 days after planting. During solarization period, rain water was accumulated in some area making the soil moisture favorable for the emergence of Cyperus rotundus.

Table 8. Weed population, pests and disease incidence of sweet potato as affected by soil solarization and nutrient management under micro-fertigation technique

\begin{tabular}{|c|c|c|}
\hline Treatment & $\begin{array}{l}\text { Fresh Weed density } \\
\quad\left(\mathrm{g}_{\text {quadrat }}{ }^{-1}\right)\end{array}$ & Pest damage $(\%)$ \\
\hline \multicolumn{3}{|l|}{ Solarization } \\
\hline $\mathrm{M}_{1}-$ with solarization & $43.17 b$ & 2.33 \\
\hline $\mathrm{M}_{2}-$ without solarization & $171.83 \mathrm{a}$ & 2.67 \\
\hline Mean & 107.50 & 2.50 \\
\hline \multicolumn{3}{|l|}{ Nutrient Management } \\
\hline $\mathrm{S}_{0}-$ Control & $90.67 b$ & $3.50 \mathrm{a}$ \\
\hline$S_{1}-$ Conventional method; no micro-fertigation & $97.83 b$ & $3.00 \mathrm{a}$ \\
\hline $\begin{array}{l}\mathrm{S}_{2}-\text { Micro-fertigation following recommended } \\
\text { rate }\end{array}$ & $114.50 \mathrm{a}$ & $2.16 b$ \\
\hline $\begin{array}{l}\mathrm{S}_{3}-\text { Aloe vera bio-organic liquid fertilizer through } \\
\text { micro-fertigation }\end{array}$ & $127.00 \mathrm{a}$ & $1.33 \mathrm{c}$ \\
\hline Mean & 107.50 & 2.50 \\
\hline
\end{tabular}

Treatment means within the same column followed by a common letters are not significantly different from each other at $5 \%$ level, Tukeys Test.

Weed population was significantly affected by nutrient management. Plots treated with aloe vera bio-organic liquid fertilizer through microfertigation achieved significantly higher weed density than the other nutrient-managed plots. The density, however, was far below the level that would harm or compete with sweet potato. Application following the recommended rate through micro-fertigation was also significantly higher in weed density than treatments without micro-fertigation. In contrast, pest damage on the non-fertigated treatments was significantly higher than those in micro-fertigated ones. Plants applied with aloe vera bio-organic liquid fertilizer had significantly lower pest damage than those plants in other nutrient-managed treatments due to the presence of microorganisms which countered or inhibited the proliferation of some pathogens.

\section{Cost and Return Analysis}

The profitability of sweet potato production as influenced by soil solarization and nutrient 
management under micro-fertigation technique revealed that soil solarization obtained higher gross margin $(5,622.78$ USD) than the nonsolarized plants with the gross margin of USD 5,448.01 (Table 9). Although micro-fertigation would provide additional production cost, however, this could give positive benefits by enhancing the root yield of the crop, thus increasing gross income.

Table 9. Cost and return analysis per hectare of sweet potato (Ipomoea batatas L. Lam) production as influenced by soil solarization and nutrient management under microfertigation technique

\begin{tabular}{|c|c|c|c|c|}
\hline Treatment & $\begin{array}{l}\text { Marketable } \\
\text { Yield } \\
\left(\mathrm{t} \mathrm{ha}^{-1}\right)\end{array}$ & $\begin{array}{c}\text { Gross } \\
\text { Income } \\
\text { (US Dollar) }^{*}\end{array}$ & $\begin{array}{l}\text { Total Variable } \\
\text { Cost } \\
\text { (US Dollar) }\end{array}$ & $\begin{array}{c}\text { Gross } \\
\text { Margin } \\
\text { (US Dollar) }\end{array}$ \\
\hline \multicolumn{5}{|l|}{ Soil Solarization } \\
\hline $\mathrm{M}_{1}-$ with solarization & 18.75 & $7,500.00$ & $1,877.22$ & $5,622.78$ \\
\hline $\mathrm{M}_{2}$ - without solarization & 16.70 & 6.680 .00 & $1,231 . .99$ & $5,448.01$ \\
\hline Mean & 17.73 & $7,090.00$ & $1,554.61$ & $5,535.39$ \\
\hline \multicolumn{5}{|l|}{ Nutrient Management } \\
\hline $\mathrm{S}_{0}-$ Control & 9.31 & $3,724.00$ & $1,020.00$ & $2,704.00$ \\
\hline $\begin{array}{l}\mathrm{S}_{1}-\text { Conventional method; no } \\
\text { micro-fertigation }\end{array}$ & 13.07 & $5,228.00$ & $1,458.44$ & $3,769.56$ \\
\hline $\begin{array}{l}S_{2}-\text { Micro-fertigation following } \\
\text { recommended rate }\end{array}$ & 19.44 & 7.776 .00 & $1,896.49$ & $5,879.51$ \\
\hline $\begin{array}{l}\mathrm{S}_{3}-\text { Aloe vera bio-organic } \\
\text { liquid fertilizer through } \\
\text { micro-fertigation }\end{array}$ & 29.09 & $11,636.00$ & $1,843.50$ & $9,792.50$ \\
\hline Mean & 17.73 & $7,091.00$ & $1,554.61$ & $5,53.39$ \\
\hline
\end{tabular}

For nutrient management, fertigated plants obtained higher income than the non-fertigated plants. Application of aloe vera bio-organic liquid fertilizer achieved the highest gross margin of USD 9,792.50. This result conformed the findings of Sivanappan (1994) who reported that micro-fertigation through drip irrigation resulted to 30-60\% water saving and an increase yield of 5-50\%. Sweet potato roots responded positively to aloe vera bio-organic liquid fertilizer which meet their need. The soil enhancement properties of aloe vera and its macro and micro element contents provide a favorable condition for the crop to grow, hence, producing higher root yield.

\section{Conclusions}

Soil solarization can control weed population and apparently produce higher total root yield. Micro-fertigation technique significantly increases the root yield of sweet potato up to 100 percent and produces larger and lessdamaged roots. Aloe vera bio-organic liquid fertilizer through micro-fertigation significantly produces higher root yield and reduces the incidence of pests and disease damage. Thus, soil solarization with aloe vera application under micro-fertigation technique is a superior tool for sweet potato production in order to achieve higher productivity and income through production of high quality marketable roots. This option is recommended particularly 
in sweet potato growing areas with unstable climatic conditions and where high vulnerability for the incidence of pests and diseases is present.

\section{Acknowledgment}

The authors would like to express their sincere thanks and gratitude to the Philippine Rootcrop Research and Training Center (PRCRTC), Visca, Baybay City, Leyte, Philippines especially to Prof. Marlon Tambis and Dr. Erlinda Vasquez for providing technical and financial support in the conduct of this research undertaking.

\section{References}

Alovebali. (2011) 'Sunland-Organic Aloe Vera based Liquid Fertilizer'. Soil Improver/ Fertilizer and Raw Material. PT ALOVE $B A L I$, Br.Tengah-Bonbiyu, Ds. SABA, Blahbatuh, Gianyar, Bali, Indonesia. Available from: http://www.aloeverafertilizer.com/ [Accessed February 9, 2018].

Aquino, J.A. (2014) 'Sweet and Purple: Meet the new sweet potato variety of UPLB'. University of the Philippines. Los Baños, Laguna. Available from: https://uplb.edu.ph/193-sweet-and-purple. [Accessed January 26, 2018].

D'Addabbo T., Miccolis V., Basile M., Candido V. (2010) Soil Solarization and Sustainable Agriculture. In: Lichtfouse E. (eds) Sociology, Organic Farming, Climate Change and Soil Science. Sustainable Agriculture Reviews, vol 3. Springer, Dordrecht doi:10.1007/978-90481-3333-8_9[Accessed January 12 2018].

Elmore, C.L., Stapleton, J.J., Bell, C.E., and Devay, J.E. (1997) 'Soil Solarization: a non pesticidal method for controlling diseases, nematodes and weeds'. UC DANR Pub. 21377. Oakland, CA, USA. p14.
FAO. (2000) 'The State of Food and Agriculture: Lessons for the Past 50 years'. Rome: Food and Agriculture Organization.

Hagan A.K., and Gazaway W.S. (2000) 'Soil Solarization for the Control of Nematodes and Soilborne Diseases'. Alabama Cooperative Extension System. Alabama A \& $\mathrm{M}$ and Auburn Universities. Available from:

http://www.aces.edu/pubs/docs/A/ANR0713/ANR-0713.pdf. [Accessed January 26, 2018].

Horowitz M., Regev Y., and Herzlinger G. (1983) 'Solarization for Weed Control'. Weed Science, 31(2), pp. 170-179. doi:10.1017/S0043174500068788.

ISRIC (International Soil Reference and Information Center). (1995) 'Procedures for Soil Analysis' (L.P. Van Reuwijk, Editor) Wageningen, The Netherlands. $106 \mathrm{pp}$.

Landon J.R. (1991) 'Brooker Tropical Soil Manual. A handbook for soil survey and Agricultural Land Evaluation in the Tropics and Subtropics'. Longman Science and Technical John Wiley and Sons, Inc. $6053^{\text {rd }}$ Avenue, New York. NY 10158475 pp.

Nelson D.W., and Sommers L.E. (1982) 'Methods of Soil Analysis', Part. American Society of Agronomy-Soil Science Society of America, 677 South Segoe Road, Madison, WI 53711, USA.

OECD. (2017) 'Agricultural Policies in the Philippines'. OECD Publishing, Paris. doi:10.1787/9789264269088-en. [Accessed February 9, 2018].

Olajire - Ayavi B.L., Dada O.V., Wahab O.M., and Ojo O. I. (2015) 'Effects of fertilizers on soil's microbial growth and populations: a review'. American Journal of Engineering Research (AJER), Volume 4, Issue 7, Dept. of Forestry Technology, Federal College Of Forestry, Ibadan, Nigeria Dept of Agricultural Engineering, Ladoke Akintola University of 
Technology, Nigeria. pp52-61. Available from:

https://www.academia.edu/14544465/Effe cts_of_fertilizers_on_soils_microbial_gro wth_and_populations_a_review.

[Accessed May 29, 2019].

Olsen S.R., Cole C.V., Watanabe F.S., and Dean L.A. (1954) 'Phosphorus'. In Method of Soil Analysis Part II. Chemical and Microbiological Properties (A. L. Page, P. H. Miller and P. R. Kurryeds.) Amer. Soc. of Agro. Inc. Madison, Wisconsin, USA. 403-430 pp.

Oso A.A., and Borisade A. (2017) Pest Profile and Damage Assessment on Three Land Races of Eggplant (Solanum spp.) in Ekiti State, Nigeria'. European Journal of Physical and Agricultural Sciences: Vol. 5 No. 1. Department of Crop, Horticulture and Landscape Design, Ekiti State University, Nigeria. Available from: https://www.idpublications.org/wpcontent/uploads/2016/12. [Accessed August 28, 2018].

O'sullivan J.N., Asher C.J., Halavatau S., Blamey F.P.C., and Yapa L.G.G. (1997) 'Nutrient disorders of sweet potato and taro': advances in diagnosis and correction in the Pacific. In: Akoroda, M.O. (ed.) Proceedings of the Sixth Triennial Symposium of the International Society for Tropical Root Crops - Africa Branch, Lilongwe Malawi, October 1995. International Institute for Tropical Agriculture.

Availablefrom:https://keys.lucidcentral.or $\mathrm{g} /$ keys/sweetpotato/key/Sweetpotato $\% 20$ Diagnotes/Media/Html/TheProblems/Min eralDeficiencies/PotassiumDeficiency/K \%20deficiency.htm. [Accessed May 29, 2019].

Parr J., Hornick S., and Kaufmman D. (1994) 'Use of microbial inoculants and organic fertilizers in agricultural production'. Proceedings of the International Seminar on the use of Microbial and Organic Fertilizers in Agricultural Production, Published by the food and fertilizer technology center, Taipei, Taiwan. 91.
PCARR. (1980) 'Standard method of analysis for soil, plant tissue water and fertilizer'. Los Baños, Laguna: Farm, Resource and Systems Research Division, Philippine Council for Agriculture and Research. 194.

Ramirez P.G. (1991) The FAO Expert Consultation on Roots, Tubers, Plantains and Bananas in Animal Feeding: Cultivation, Harvesting and Storage of Sweet potato Products. Centro Internacional de Agricultura Tropical (CIAT). Colombia.

Salvador R.M. (2019) 'Performance of sweet potato (Ipomoea batatas L. Lam) to soil solarization and nutrient management under micro-fertigation technique'. Undergrad. Thesis. VSU, Visca, Baybay City, Leyte. 71 pp.

Salvador R.M., and Bañoc D.M. (2020) 'Performance of sweet potato (Ipomoea batatas L. Lam) to soil solarization and nutrient management under microfertigation technique'. International Journal of Agricultural Sciences. [Submitted].

Sivanappan R.K. (1994) 'Prospects of microirrigation in India'. Irrigation and Drainage Systems.

Valenzuela, H., Fukuda S., and Arakaki A. (2019) Sweet potato guidelines for Hawaii. Associate Extension Vegetable Specialist, County Extension Agent, and County Extension Agent, respectively, CTAHR, University of Hawaii. Available at: http://www.extento.hawaii.edu/kbase/repo rts/sweetpot_prod.htm. [Accessed May 29, 2019]. 